WSRC-TR-2002-00348

Revision 0

EXPANDING RING FOR THE DWPF MELTER POUR SPOUT (U)

\author{
HAROLD B. PEACOCK \\ KENNETH J. IMRICH \\ POH-SANG LAM \\ DOUGLAS R. LEADER
}

SAVANNAH RIVER TECHNOLOGY CENTER

Publication Date: August 12, 2002

Westinghouse Savannah River Company Savannah River Site Aiken, SC 29808 
This document was prepared in conjunction with work accomplished under Contract No. DE-AC09-96SR18500 with the U. S. Department of Energy.

\section{DISCLAIMER}

This report was prepared as an account of work sponsored by an agency of the United States Government. Neither the United States Government nor any agency thereof, nor any of their employees, makes any warranty, express or implied, or assumes any legal liability or responsibility for the accuracy, completeness, or usefulness of any information, apparatus, product or process disclosed, or represents that its use would not infringe privately owned rights. Reference herein to any specific commercial product, process or service by trade name, trademark, manufacturer, or otherwise does not necessarily constitute or imply its endorsement, recommendation, or favoring by the United States Government or any agency thereof. The views and opinions of authors expressed herein do not necessarily state or reflect those of the United States Government or any agency thereof.

This report has been reproduced directly from the best available copy.

Available for sale to the public, in paper, from: U.S. Department of Commerce, National Technical Information Service, 5285 Port Royal Road, Springfield, VA 22161, phone: (800) 553-6847, fax: (703) 605-6900

email: orders@ntis.fedworld.gov

online ordering: http://www.ntis.gov/help/index.asp

Available electronically at http://www.osti.gov/bridge

Available for a processing fee to U.S. Department of Energy and its contractors, in paper, from: U.S. Department of Energy, Office of Scientific and Technical Information, P.O. Box 62, Oak Ridge, TN 37831-0062,

phone: (865)576-8401,

fax: (865)576-5728

email: $\underline{\text { reports@ adonis.osti.gov }}$ 
Keywords:

DWPF

Melter

BLD-210-S

Insert

Retention: Permanent

\title{
Expanding Ring for DWPF Melter Pour Spout (U)
}

\section{Harold B. Peacock, Kenneth J. Imrich,} Poh-Sang Lam, \& Douglas R. Leader

\author{
Issued:
}

August 12, 2002

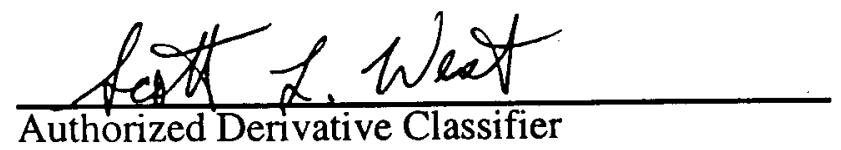

Date: $8 / 12 / 2002$

Authorized Derivative Classifier 
DOCUMENT: WSRC-TR-2002-00348 Revision 0

TITLE: EXPANDING RING FOR DWPF MELTER POUR SPOUT (U)

APPROVALS

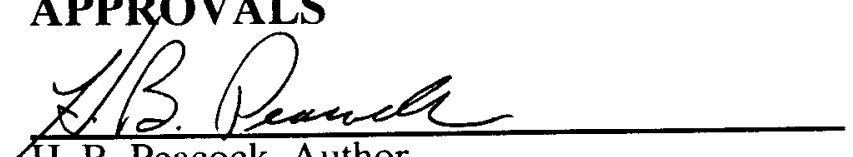

H. B. Peacock, Author

Materials Technology Section

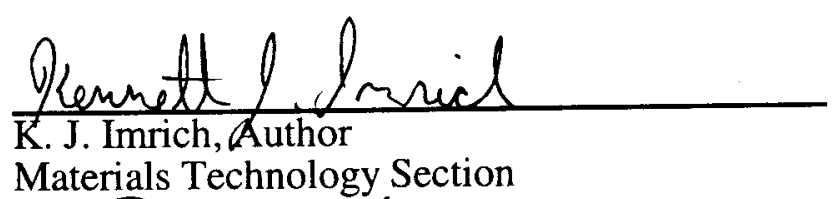

Materials Technology Section

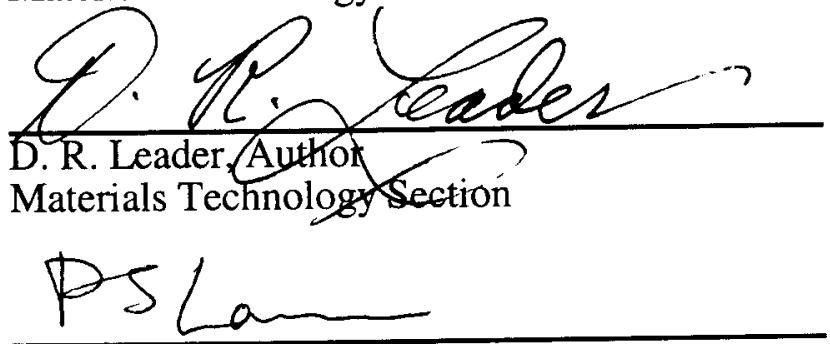

PS Lam, Author

Materials Technology Section

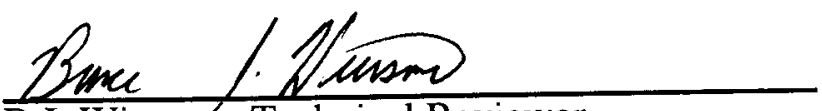

B.J. Wiersma, Technical Reviewer Materials Technology Section

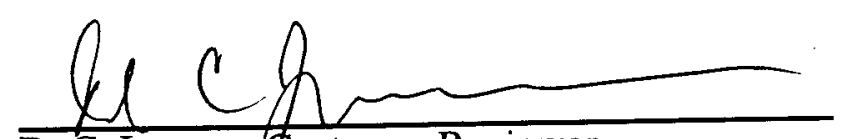

D. C. Iverson, Customer Reviewer DWPF Process COG Engineering

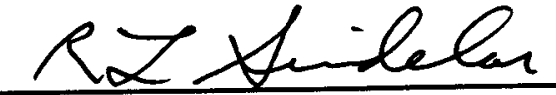

R.L. Sindelar, Manager

Materials Applications \& Corrosion Technology Group Materials Technology Section

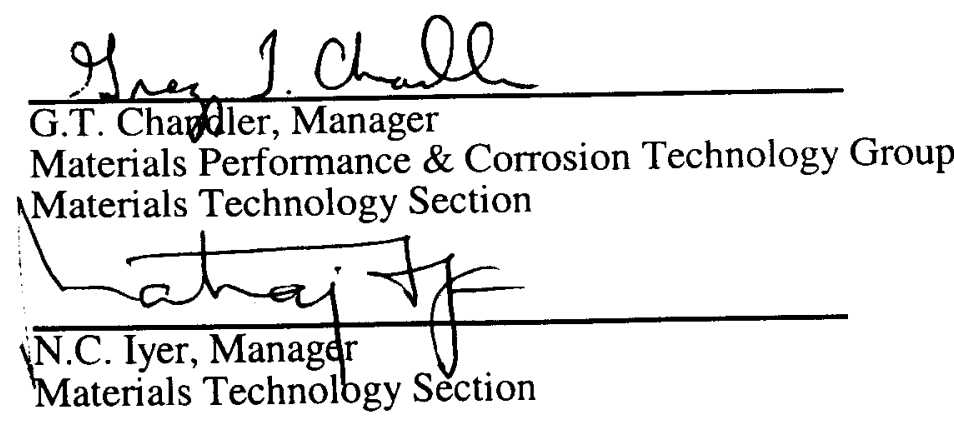

Date:

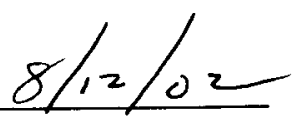

Date: $8 / 12 / 02$

Date:

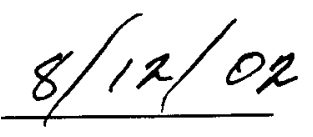

Date:

$8 / 12 / 02$

Date: $8 / 12 / 02$

Date: $8 / 12 / 02$

Date: $8 / 12 / \phi 2$

Date: $8 / 12 / 02$

Date: $8 / 12 / 02$ 


\section{TABLE OF CONTENTS}

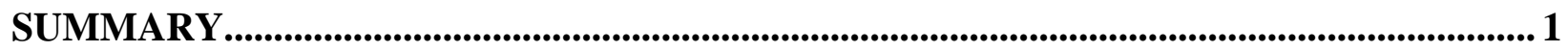

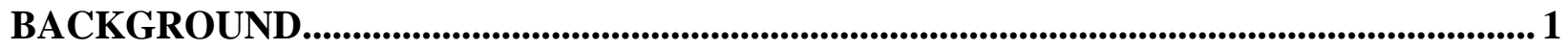

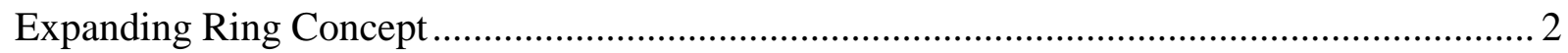

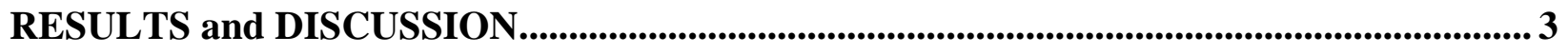

Finite Element Model ................................................................................................ 3

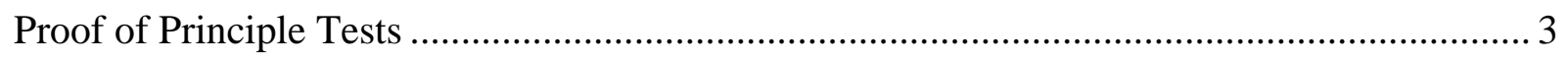

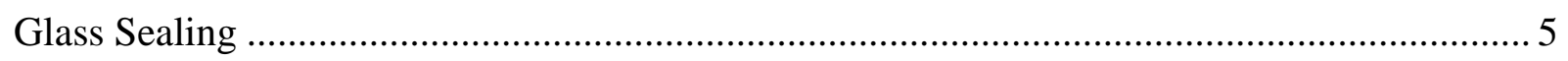

Force Required to Initiate Movement of Ring ............................................................. 5

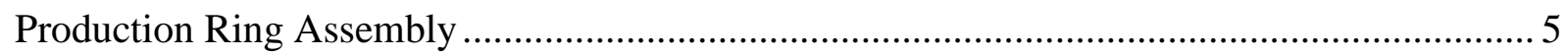

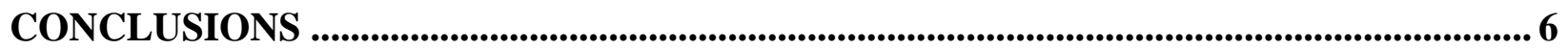

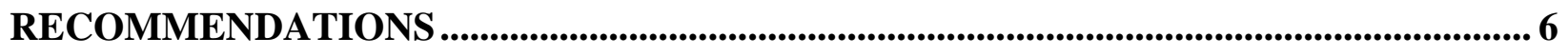

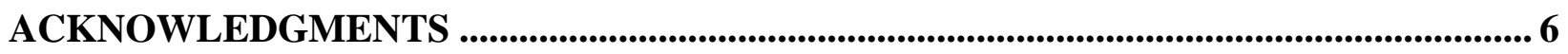

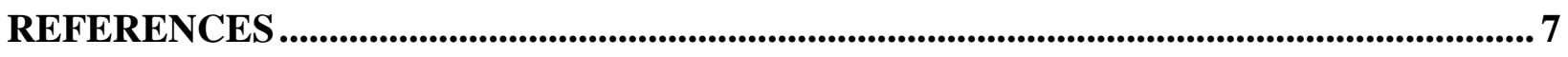

ATTACHMENT 1 ....................................................................................................................... 18 


\section{LIST OF TABLES}

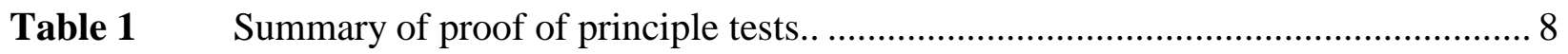

\section{LIST OF FIGURES}

Figure 1 Schematic of the DWPF melter pour spout showing removable insert installed below the lower knife edge in the 3 inch section.................................................. 9

Figure 2a Schematic of the DWPF melter pour spout showing removable insert installed below the lower knife edge in the 3 inch section.

Figure 2b Cross-sectional view of the expanding ring assembly and Type 3A insert installed in the pour spout.

Figure 3 Mises stress results from the finite element analysis of an axisymmetric model for the Inconel 690 expanding ring with an initial 1/8" radial clearance.

Figure 4 Calculated pressure and cavity volume changes as a function of temperature for the Type I expanding ring.

Figure 5 Initial proof of principle test prior to elevated temperature exposure . .................. 13

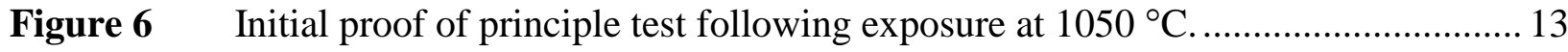

Figure 7 UT data for 304 ring and Inconel 600 spout expanded at $1050^{\circ} \mathrm{C}$ with $1 / 16$ inch

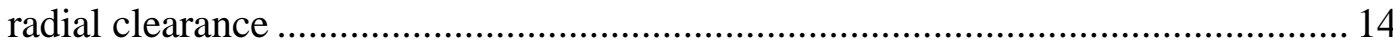

Figure 8 Destructive evaluation of 304-L ring inside 304-L simulated pour spout with $1 / 16$ inch radial clearance after static molten glass exposure.

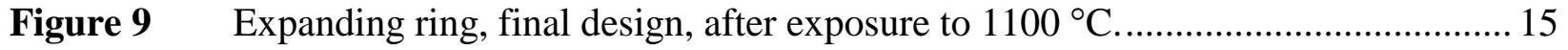

Figure 10 Experimental and calculated ring expansion for $1 / 8$ inch radial gap including 0.030 including 0.03 inch contoured groove...

Figure 11 Temperature profile of the 690 ring in a 690 simulated pour spout heated to $1100{ }^{\circ} \mathrm{C}$. 16

Figure 12 Photograph of the final production expanding ring assembly 17 


\section{Expanding Ring for DWPF Melter Pour Spout (U)}

\section{SUMMARY}

The Materials Technology Section (MTS) was requested to develop a novel concept, namely that of an expanding ring, to restore the upper knife edge in the DWPF melter pour spout. The expanding ring is a unit that, when deployed into the DPWF pour spout, will self-expand against the inner diameter of the 3 inch section of the pour spout providing a seal against glass leakage and a new knife edge that will mate with a Type $3 \mathrm{~A}$ insert. This report provides a summary of the final design (Type II) features of the expanding ring and an overview of its development. Proof-of-principle tests were also performed to demonstrate the successful engagement and sealing capabilities of the expanding ring in a simulated pour spout. Recommendations for the deployment of the expanding ring in the DWPF pour spout are provided.

Proof of principle tests were successfully performed to demonstrate the ability of the expanding ring to seal molten glass at $1100{ }^{\circ} \mathrm{C}$ and to remain engaged without slippage under anticipated operating conditions. Laboratory tests showed that a glass tight seal could be formed in an irregularly shaped pour spout with an initial radial clearance of up to 3/16 inches. The axial contact length between the simulated pour spout and the ring for the final Type II design (1/8 inch radial clearance) was approximately 0.75 inches and the time necessary for the ring to engage the pour spout was approximately 8 minutes. A static load of approximately $70 \mathrm{lbs}$ was required to initiate movement of the ring that had been at $1100{ }^{\circ} \mathrm{C}$ for 4 hours. However, the load increased to $340 \mathrm{lbs}$ after 2.5 weeks of elevated temperature exposure. No significant dimensional change in the inner diameter of the ring was noted after 2.5 weeks exposure. No deformation of the DWPF pour spout is expected due to the force exerted by the expanding ring.

MTS recommends the installation of the Type II expanding ring into the DWPF melter pour spout. In the event of an installation problem, the expanding ring must be removed from the DWPF melter pour spout prior to an elapsed time of 6 minutes due to expansion of the ring causing an increase in its dimensions through elevated temperature exposure. After insertion the ring should be supported for 24 minutes prior to removing the installation tool. This will ensure that the ring is secure.

\section{BACKGROUND}

The Defense Waste Processing Facility (DWPF) at SRS receives sludge from the waste tanks and processes it with nitric and formic acids, adds borosilicate frit. The slurry is transferred to the melter where the molten glass is poured into stainless steel canisters. The canisters will be used for long-term storage of radioactive waste in a geological repository. The DWPF melter was installed at SRS about 8.5 years ago and had a design life of 2 years.

The molten glass flows up the melter riser where it then falls down the pour spout into a stainless steel waste canister below. Two knife edges in the pour spout are intended to allow the molten glass to disengage the pour spout and fall freely into the center of the canister (Figure 1). The knife edges ( 2 inch to 3 inch transition and the 3 inch to 4 inch transition) are maintained at 1100 ${ }^{\circ} \mathrm{C}$ with external heaters. The lower most 4 inch section has a gradient from $1100{ }^{\circ} \mathrm{C}$ at the lower knife edge to approximately $500{ }^{\circ} \mathrm{C}$ at the bottom. Over the years, molten glass corrosion and 
erosion of the upper knife edge has resulted in the pour stream wicking down the side of the pour spout. This condition has resulted in a significant reduction in melter through-put due to the frequent need for cleaning glass from the lower spout. Degradation of the pour spout in the 2 inch section has created a somewhat elliptical shaped spout with the most severe degradation occurring in the glass contact portion.

Pour spout inserts were developed 5 years ago and have successfully extended the life of the melter. The insert fits against the degraded upper knife edge to stabilize the pour stream by collecting and redirecting the molten glass down into the canister (Figure 1). The insert is remotely installed into the pour spout and until recently have made a reasonably effective glass tight seal with the upper knife edge. However, some glass has been able to seep behind the insert and further degrade the knife edge. Over time further degradation of the knife edge has occurred and the inserts are no longer able to provide an effective seal. DWPF has requested assistance in developing a method to seal against the spout wall and provide a new knife edge for inserts in order to extend the service life of the melter.

DWPF Engineering requested STRC to evaluate the problem and recommend solutions based on two basic design criteria, 1) permanent installation, and 2) a 1/8 inch radial clearance for installation of a device into the 3 inch bore. The latter was requested for ease of installation. MTS proposed an active system consisting of an Inconel 690 expanding ring that will seal circumferentially around the irregular pour spout wall. This concept was fully developed and an expanding ring is ready for deployment in the DWPF pour spout. This report provides a summary of the final design (Type II) features of the expanding ring and an overview of its development.

\section{Expanding Ring Concept}

Degradation of the pour spout upper knife edge has made sealing of the inserts extremely difficult if not impossible. An expanding ring that is capable of sealing circumferentially against the irregular wall surface and provides an edge for modified inserts has been developed. The expanding ring is a cylindrical device with a thin outer wall and a thick inner wall. The walls surround an annular chamber that is filled with pressurized helium. When the device is inserted in the $1100{ }^{\circ} \mathrm{C}$ pour spout, it begins to heat up. At approximately $900{ }^{\circ} \mathrm{C}$ the internal pressure has increased while the yield strength has decreased sufficiently to "balloon" the outer wall. This expansion continues until it makes contact with the inner wall of the pour spout. Because the metal is perfectly plastic at this temperature it can conform to the elliptical shape of the degraded pour spout.

The expanding ring is made from Inconel 690, a high temperature nickel based alloy, with excellent oxidation and molten glass corrosion resistance. Because the melter pour spout is also made from 690, there are no thermal expansion, corrosion or glass incompatibility issues.

Dimensions of the internal cavity and thus, the helium fill pressure were driven by the DWPF Engineering requirements of a 1/8-inch radial clearance between the outer diameter of the ring and the pour spout wall and an inner wall thickness of $1 / 4$ inch. In addition, the inner diameter needed to be 2 inches to match the original ID of the upper pour spout. Corrosion allowance for the glass contact surface was deemed important, but not considered a primary concern.

The expanding ring consists of two concentric cylinders electron beam welded together. The outer cylinder wall thickness is 1/16 inch and the inner cylinder wall thickness is $1 / 4-i n c h$. When assembled, an internal gas cavity is formed between the rings as shown in Figure 2a [1]. A 1/8 inch diameter Inconel 690 fill stem with a 1/32 inch inner diameter is Gas Tungsten Arc (GTA) welded to the bottom of the ring so the ring cavity can be purged to remove residual moisture and filled with helium gas. The helium pressure at room temperature is about $425 \mathrm{psi}$. The fill pressure was determined from finite element modeling and confirmed by laboratory testing. 
The upper surface that mates with the pour spout is an integral portion of the expanding ring while the lower knife edge, which covers the fill stem, is added to the assembly after the ring is electron beam welded and pressurized with Helium gas. The assembled component, including upper and lower edges, is about 3.5 inches long. The lower edge of the expanding ring assembly will mate with a shortened Type $3 \mathrm{~A}$ insert, shown in Figure $2 \mathrm{~b}$.

\section{RESULTS AND DISCUSSION}

\section{Finite Element Model}

Finite element modeling was used to aid ring design by investigating the deformation characteristics of the ring under pressure loads and to determine the stress distribution in the pour spout sidewall. Axisymmetric models of the ring and the DWPF sidewall were constructed and analyzed using the ABAQUS code.

As the ring temperature increases the gas pressure will increase until the stress level in the material reaches its yield strength at temperature resulting in the expansion of the outer wall. Expansion continues until it reaches the pour spout wall as shown in the example model in Figure 3.

The gas pressure within the cavity was calculated as a function of temperature using the Ideal Gas Law. The material was considered nearly perfectly plastic at $1050{ }^{\circ} \mathrm{C}$, and thermal expansion of the ring was considered in the calculations. The temperature-dependent stressstrain characteristics of Inconel 690 were obtained from test data from the literature [2]. Based on the cavity dimensions for the Type I design with a 1/8 inch radial clearance, the initial gas volume was calculated to be $0.63 \mathrm{in}^{3}$ and the initial fill pressure was assumed to be 400 psi at room temperature, approximately $300 \mathrm{~K}$.

The final stress distributions after deformation are shown in Figure 3 for both the ring and the pour spout. The 1/16-inch thick outer wall of the ring yields and begins expanding at a calculated Mises stress of about 4600 psi. (Mises stress is an equivalent stress which can be reduced to the one-dimensional stress in the case of a uniaxial tension test) The stress level is lower for the thicker inner wall of the ring and was calculated to be less than 3000 psi maximum. The deformation is limited essentially to the outer ring. When the ring is fully expanded, the stress on the pour spout wall is expected to be less than $1000 \mathrm{psi}$ at the contact region. Therefore no significant deformation of the spout is expected.

A final pressure of 600 psi results when the ring has completely expanded and deformed against the wall. The calculated axial contact length along the pour spout wall was about 0.4 inch. After expansion, the cavity volume is approximately $1.84 \mathrm{in}^{3}$. The calculated gas pressure inside the cavity and volume are shown in Figure 4 as a function of temperature. For this case, a maximum pressure of about 1300 psi occurs prior to yielding at about $750{ }^{\circ} \mathrm{C}$.

The expanding ring is considered to be an active device because as long as the internal gas pressure remains at about $600 \mathrm{psi}$, at temperature, the outer wall of the ring will continue to press against the inner surface of the DWPF pour spout. Diffusion of helium gas is extremely low in solid solution alloys such as Inconel 690, and therefore, there will be essentially no diffusion of helium gas out of the cavity.

\section{Proof of Principle Tests}

The initial laboratory proof of principle test was performed using a $304 \mathrm{~L}$ stainless steel expanding ring and an Inconel 600 simulated pour spout (Figure 5). Tests were carried out in a massive glo-bar furnace in the MTS Laboratory. Table 1 lists the various test performed as part 
of the proof of principle program. Type $\mathrm{K}$ thermocouples were attached inside the simulated pour spout and on the expanding ring. A radial clearance of 0.010 inch was used in the first test. The ID of the simulated pour spout contained a contoured groove that was machined 0.030 inch deep by approximately 1.25 inch wide along its entire length. This machined groove was added to simulate the degraded region of the melter pour spout.

Some difficulty was encountered when inserting the ring into the pour spout at $1050{ }^{\circ} \mathrm{C}$ and was attributed to the small radial, 0.01 inch, clearance and tooling design (Table 1, test 1a). This test successfully demonstrated that the ring would expand radially and would fill the 0.030 inch contoured groove (Figure 6, Table 1 test 1a). The ring was removed and retested in a pour spout with a $1 / 16$ inch radial clearance (Table 1, test $1 \mathrm{~b}$ ). After sealing, glass frit was placed in a reservoir on top of the ring and heated at $1050{ }^{\circ} \mathrm{C}$ for about 4 hours. No glass seeped past the seal between the ring and the pour spout (Table 1, test 1c). In addition, no movement of the ring was observed while subjected to a $15 \mathrm{lb}$ static load.

To assess the quality of the seal, nondestructive methods such as ultrasonic testing (UT) and digital radiography (DR) were employed. The seal was tight enough to allow measurement of the outer wall of the ring with UT. Intimate axial contact between the ring and the pour spout was 0.3 inches. Although the signal intensity was lower, the wall thicknesses of both the spout and ring could be discerned approximately 0.22 inches on either side of the intimate contact zone (Figure 7).

The final test of the $304 \mathrm{~L}$ ring involved cutting the fill stem and releasing the internal pressure. This ring was then statically loaded with approximately $15 \mathrm{lbs}$ while at temperature. No movement or glass seepage around the ring was observed (Table 1 test 1d). Finally the ring was destructively evaluated to confirm the UT and DR data. Figure 8 shows the cross section, which verified the UT data.

Subsequent tests were performed using Inconel 690 components (Table 1, Nos. 3 and 4). Simulated pour spouts were fabricated using a 5.5 inch outside diameter by 4 inch long Inconel 690 round stock with a 3 -inch inside bore to simulate the pour spout. Again the ID was machined so there was a 0.030 -inch deep by 1.25 inch wide (approximately 40 degree arc) contoured groove along its entire length. Radial clearances up to $3 / 16$ inch between the ring OD and the simulated pour spout wall were successfully tested. Typical axial contact length between the simulated pour spout and the Inconel 690 ring was approximately 0.75 inches (Figure 9). Based on the results, DWPF requested development of an expanding ring with a 1/8 inch radial clearance.

Using the calculated final pressure of $600 \mathrm{psi}$ and knowing the various volumes and temperatures, the initial fill pressure $\left(\mathrm{P}_{1}\right)$ could be calculated using equation (1),

$$
\frac{\mathrm{P}_{1} \mathrm{~V}_{1}}{\mathrm{~T}_{1}}=\frac{\mathrm{P}_{2} \mathrm{~V}_{2}}{\mathrm{~T}_{2}}
$$

where 1 refers to the initial state and 2 the final state and temperature $(\mathrm{T})$ is in degrees Kelvin.

A test was performed to determine ring expansion as a function of time. The information was used to establish the time for installation. Type $\mathrm{K}$ thermocouples were attached inside the simulated pour spout and on the expanding ring. The simulated pour spout was heated and stabilized at $1050{ }^{\circ} \mathrm{C}$ in the furnace after which the room temperature ring was inserted. An Inconel 690 push rod, already at temperature, was used to measure the expansion of the ring. Figure 10 shows the experimental results and compares the data with finite element calculations. The curves are similar in shape, but the experimental results indicate that the on-set of rapid expansion occurs at about $940{ }^{\circ} \mathrm{C}$ as compared to $820{ }^{\circ} \mathrm{C}$ for the calculated results. The calculated and experimental results show that the ring engages the wall at 900 to $1000{ }^{\circ} \mathrm{C}$, 
respectively. The initial expansion observed in the experiment (Table 1, No. 3) is misleading and most likely is due to furnace temperature profile, machining tolerances and movement of the ring when beginning the measurements.

The time to reach about $940{ }^{\circ} \mathrm{C}$ was determined from ring temperature measurements shown in Figure 11. To reach $820^{\circ} \mathrm{C}$ takes about 6 minutes. This excludes the thermal inertia of the insert attachment and insertion tool. If difficulties arise during insertion, the ring can be safely removed before 6 minutes. However, after approximately 8-10 minutes, the ring will be firmly engaged and much more difficult to remove.

Sufficient soak time is needed to guarantee that the ring is properly seated and engaged against the pour spout wall at $1100{ }^{\circ} \mathrm{C}$ before the insertion tool is removed; otherwise the ring will not be seated properly and may fall out. This time is conservatively set at $3 \mathrm{X}$ the experimental engagement time or approximately 24 minutes. This should provide enough time to completely heat the assembly, insertion tool and ring to the operating temperature. Insertion tooling should be capable of surviving extended elevated exposure.

\section{Glass Sealing}

Qualitative tests to determine the nature of the seal between the device and the pour spout wall showed that there was no measurable leakage of glass at temperature. In the absence of glass there was a leakage of argon of approximately 2 SCFH of argon gas at 8 psi, but with glass present in the mockup, which represents the condition in the DWPF pour spout, there was no measurable leakage.

\section{Force Required to Initiate Movement of Ring}

Tests were conducted to verify that the expanding ring would not be displaced by the forces generated by the melt pour stream. These tests were performed with the simulated pour spout and an expanding ring with the same dimensions as the Type II design. In one test it was determined that approximately 75 pounds of force was required to move the ring after it had been heated for several hours (Table 1, No. 3). This test was performed with a freshly coated glass surface, to simulate conditions in the DWPF pour spout, and in a horizontal orientation. Pressure was applied with a spring and pressurized gas.

A second removal test using argon gas was performed after the component had been heated in the furnace at $1100{ }^{\circ} \mathrm{C}$ for $2 \frac{1}{2}$ weeks (Table 1, No. 4). Similar to the first test, the pour spout was coated with molten glass before the ring was inserted but no additional glass was added. In this test, the ring was loaded vertically with a 15 pound weight during the $2-1 / 2$ weeks at $1100{ }^{\circ} \mathrm{C}$ to verify that it would not creep under load. The force required to remove this ring was 340 pounds. No vertical movement (slippage) of the ring occurred. Additionally, the inside diameter of the ring did not change significantly $(<0.015$ inches $)$ during the test period. This amount of deformation should not impact pour stream.

\section{Production Ring Assembly}

After development of the expanding ring, additions to both the top and bottom ends of the ring were designed to mate with the DWPF pour spout upper knife edge and the Type 3A insert (Figure 12). At the request of DWPF Engineering the radial clearance between the upper and lower additions and the DWPF pour spout is 1/16 inch. The final Type II design, including detailed notes to aid fabrication, is shown in Attachment 1 [1].

Based on previously measured corrosion rates from the DWPF melter pour spout insert [3], the inner diameter of the ring should have an expected service life of approximately 3 years. Since all components used to fabricate the ring are made from Inconel 690, corrosion of the ring will 
not affect glass chemistry or impact waste acceptance. Although the outer wall is much thinner, it should not be exposed to fresh flowing glass, and therefore, significant molten glass corrosion of this portion of the ring is not anticipated.

\section{CONCLUSIONS}

Based on the results of the expanding ring proof of principle tests the conclusions are:

1) Radial expansions of up to $3 / 16$ inch can be obtained with the currently designed expanding ring.

2) A glass tight circumferential seal could be obtained even in the contoured groove.

3) An initial fill pressure of 425 psi should be used for the current expanding ring design with $1 / 8$ inch radial clearance.

4) Static loads up to $70 \mathrm{lbs}$ can be supported before initiating ring movement (several day test). A significantly higher load $(340 \mathrm{lbs})$ is required to initiate movement after extended elevated temperature exposure.

5) After ring expansion internal pressure is not required for continued operability.

6) No significant change in the ring's inner diameter was observed after extended elevated temperature exposure.

7) No deformation of the DWPF pour spout is expected from the force exerted by the expanding ring.

\section{RECOMMENDATIONS}

The following recommendations are based on the conclusions from the proof of principle tests.

1) The Type II expanding ring fabricated entirely from Inconel 690 (including the fill stem), with a 1/8 inch radial clearance, and a 425 psi helium gas pressure is recommended for installation in the DWPF melter pour spout.

2) In the event of an installation problem, the expanding ring must be removed from the DWPF melter pour spout prior to an elapsed time of 6 minutes elevated temperature exposure.

3) The ring should be supported for 24 minutes (3X safety factor) prior to removing the installation tool.

\section{ACKNOWLEDGMENTS}

The authors would like to express their appreciation to the following individuals for their commitment to this task, Brantley Poss (Bechtel Construction), Gregg Creech, Glenn McKinney, David Maxwell, Bill Hinz (Materials Technology Section), Tommy McCoy, William Best, Gary Bailey, Thomas Eubanks, Michael Stowell, Micah Boylston (RSE Development Machine Shop), Charles Stillwell, David Worrall, Juan Hill, Larry Parker (RSE Development Support), Chris Allen, George Crow (NDE Systems, High Pressure Lab), David Immel (NDE Systems), and Malcolm Kyle, Phil French, Jeff Brault, (Remote Specialty Equipment). 


\section{REFERENCES}

1) Equipment Engineering Development Drawing Number EES-22613-R3-202 Rev. B, DWPF Pour Spout Expandable Ring Weldment and Details Type II (U), Drawing to be superseded by Record Drawing R-R1-S-0042 Rev. A.

2) Venkatesh V. and Rack, H.J., "Elevated temperature hardening of INCONEL 690," Mechanics of Materials 30(1998) pp. 69-81, February 1998.

3) K.J. Imrich, Metallurgical Evaluation of the DWPF Melter Pour Spout Insert No. 1, WSRC TR-98-00104. 
Table 1. Summary of proof of principle tests.

\begin{tabular}{|c|c|c|c|c|c|}
\hline $\begin{array}{l}\text { Test } \\
\text { No. }\end{array}$ & $\begin{array}{c}\text { Ring } \\
\text { Material }\end{array}$ & $\begin{array}{c}\text { Pour Spout } \\
\text { Material }\end{array}$ & $\begin{array}{l}\text { Radial } \\
\text { Clearance } \\
\quad \text { (in) }\end{array}$ & $\begin{array}{l}\text { Groove } \\
\text { Depth } \\
\text { (in) }\end{array}$ & Comments \\
\hline $1 \mathrm{a}$ & $304 \mathrm{~L}$ & Inconel 600 & 0.010 & 0.030 & $\begin{array}{c}\text { No glass } \\
\mathrm{P}_{1}=110 \mathrm{psi}\end{array}$ \\
\hline $1 b$ & $\begin{array}{l}\text { Reused ring } \\
\text { No. 1a }\end{array}$ & $304 \mathrm{~L}$ & $1 / 16$ & 0.000 & No glass \\
\hline $1 \mathrm{c}$ & $\begin{array}{l}\text { Reused ring } \\
\text { No. 1a }\end{array}$ & $\begin{array}{l}\text { Reused spout } \\
\text { No. 1b }\end{array}$ & & & Static * \\
\hline $1 d$ & $\begin{array}{l}\text { Reused ring } \\
\text { No. 1a }\end{array}$ & $\begin{array}{l}\text { Reused spout } \\
\text { No. 1b }\end{array}$ & & & $\begin{array}{c}\text { Static * } \\
\text { cut fill stem }\end{array}$ \\
\hline 2 & Inconel 690 & Inconel 600 & $1 / 16$ & 0.030 & $\begin{array}{c}\text { Static } * \\
\mathrm{P}_{1}=180 \text { psi }\end{array}$ \\
\hline $2 \mathrm{a}$ & $\begin{array}{l}\text { Reused ring } \\
\text { No. } 2\end{array}$ & Inconel 600 & $3 / 16$ & 0.030 & Precoated $* *$ \\
\hline 3 & Inconel 690 & Inconel 690 & $1 / 8$ & 0.030 & $\begin{array}{l}\text { Precoated } * * \\
\mathrm{P}_{1}=425 \text { psi }\end{array}$ \\
\hline 4 & Inconel 690 & Inconel 690 & $1 / 8$ & 0.030 & $\begin{array}{l}\text { Precoated }{ }^{* *} \\
\mathrm{P}_{1}=425 \text { psi } \\
2.5 \text { week test }\end{array}$ \\
\hline
\end{tabular}

* Glass placed in reservoir above ring

** Precoated pour spout with glass 


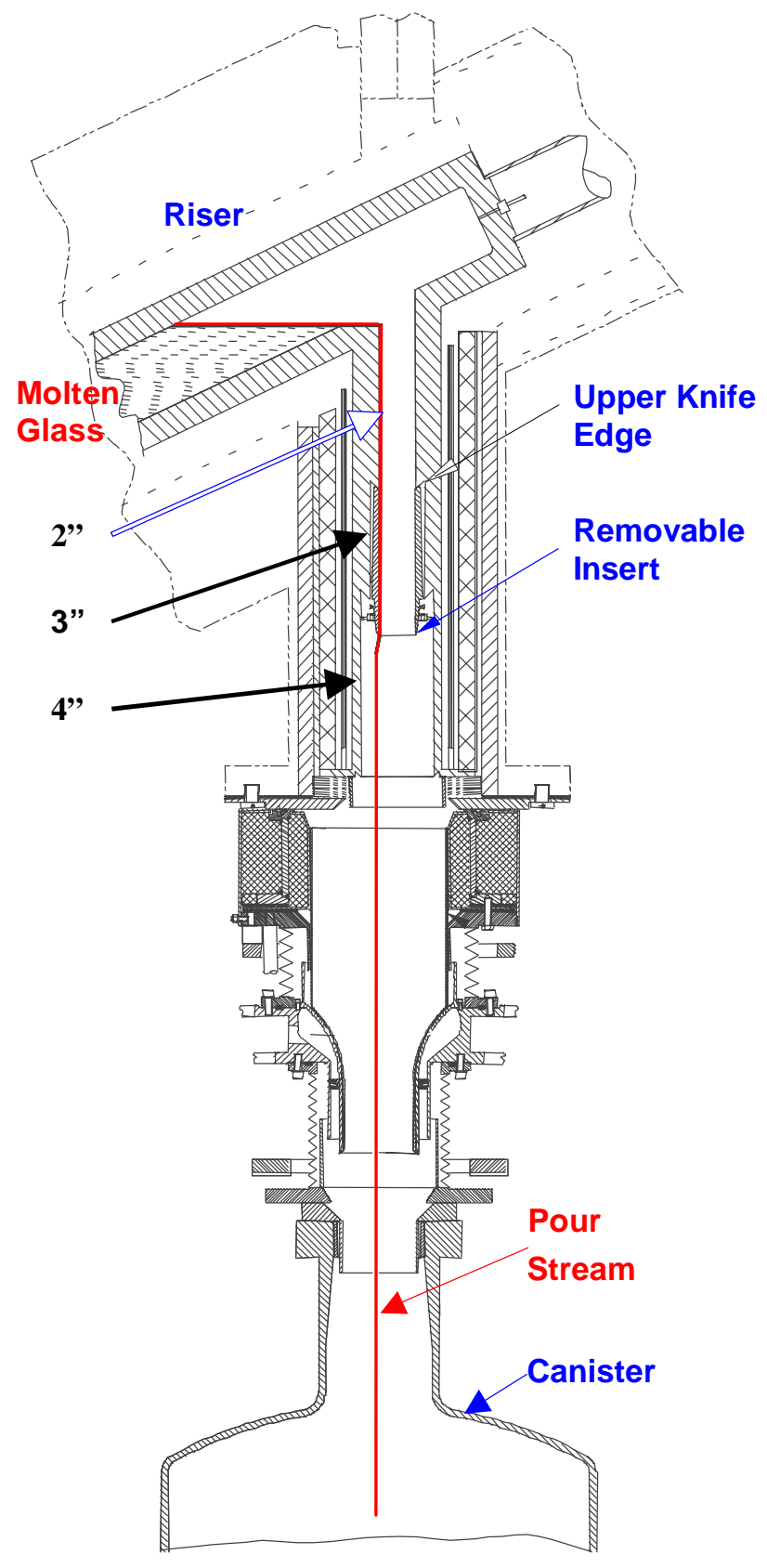

Figure 1. Schematic of the DWPF melter pour spout showing removable insert installed below the lower knife edge in the 3 inch section. Corrosion and erosion of the pour spout has mainly occurred in the 2 inch section on the melter (glass contact) side. 
Page 10 of 18

WSRC-TR-2002-00348

Rev.0

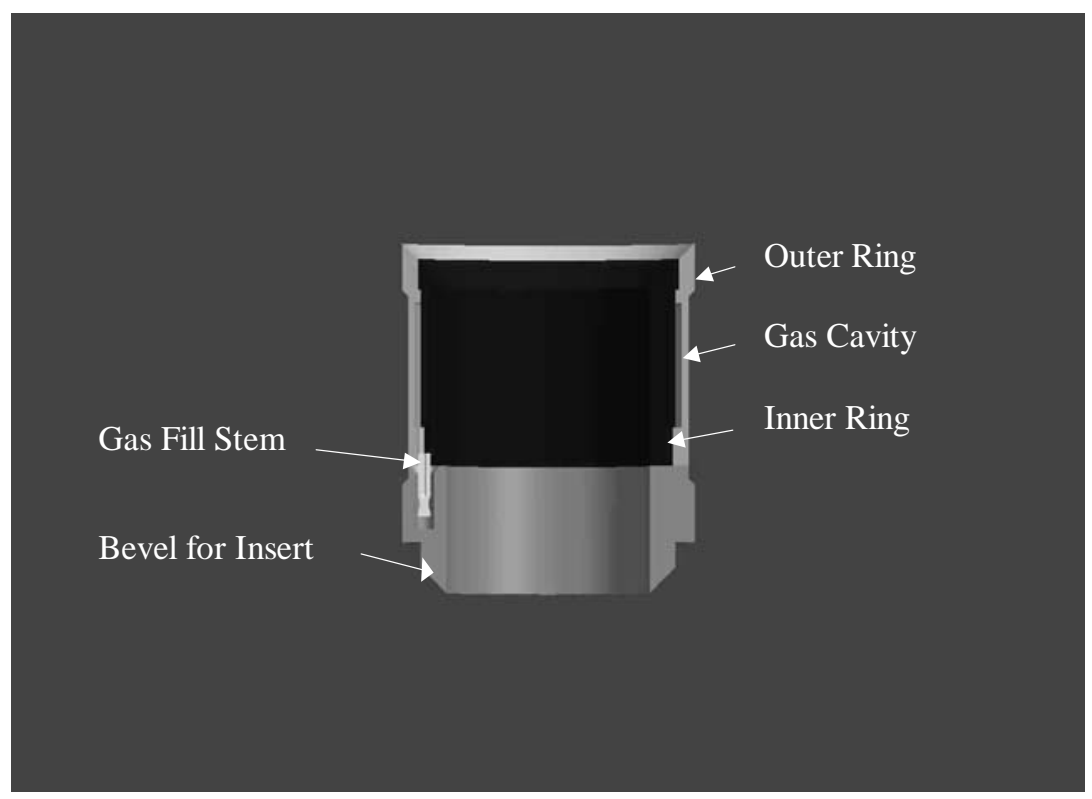

Figure 2a. Expanding ring with insert attachment (attachment 1).

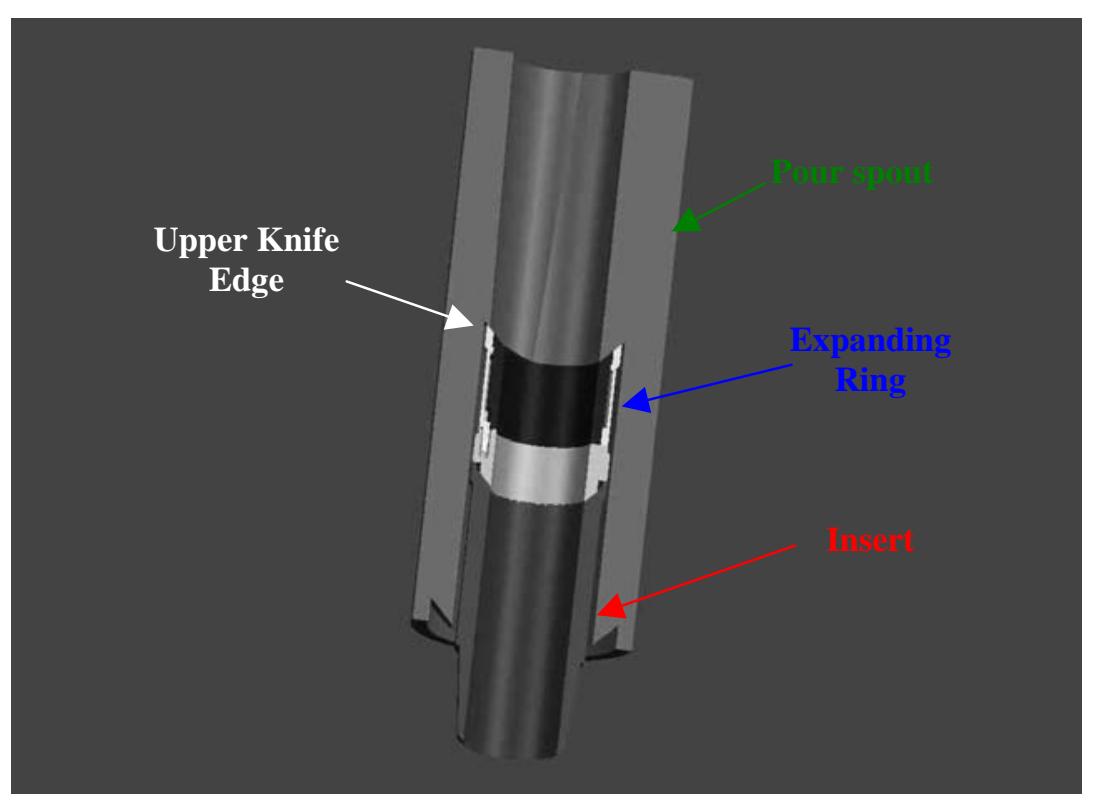

Figure $2 \mathrm{~b}$. Cross-sectional view of the expanding ring assembly and Type $3 \mathrm{~A}$ insert installed in the pour spout. 

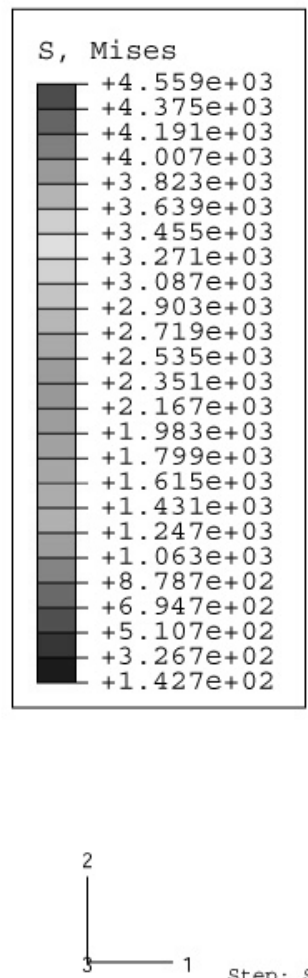

Step: Step-1, Raising Temperature from Increment $80:$ Step Time $=1.000$ Primary Var: $s$, Mises

\section{\begin{tabular}{ll} 
Ring & Pour Spout \\
\hline
\end{tabular}}

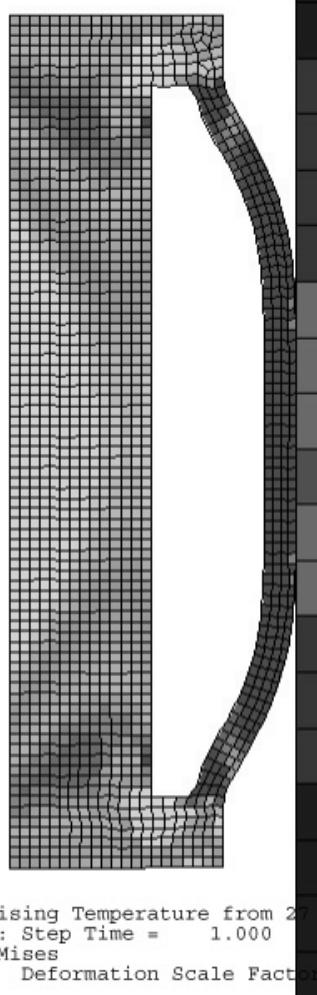

Figure 3. Mises stress results from the finite element analysis of an axisymmetric model for the Inconel 690 expanding ring with an initial 1/8" radial clearance. The deformation shown is for a cavity pressure of 600 psig with the ring at $1050^{\circ} \mathrm{C}$. Calculations were stopped when the ring adequately contacted the pour spout, approximately 0.4 inches. This defined the final cavity volume and gas pressure. 


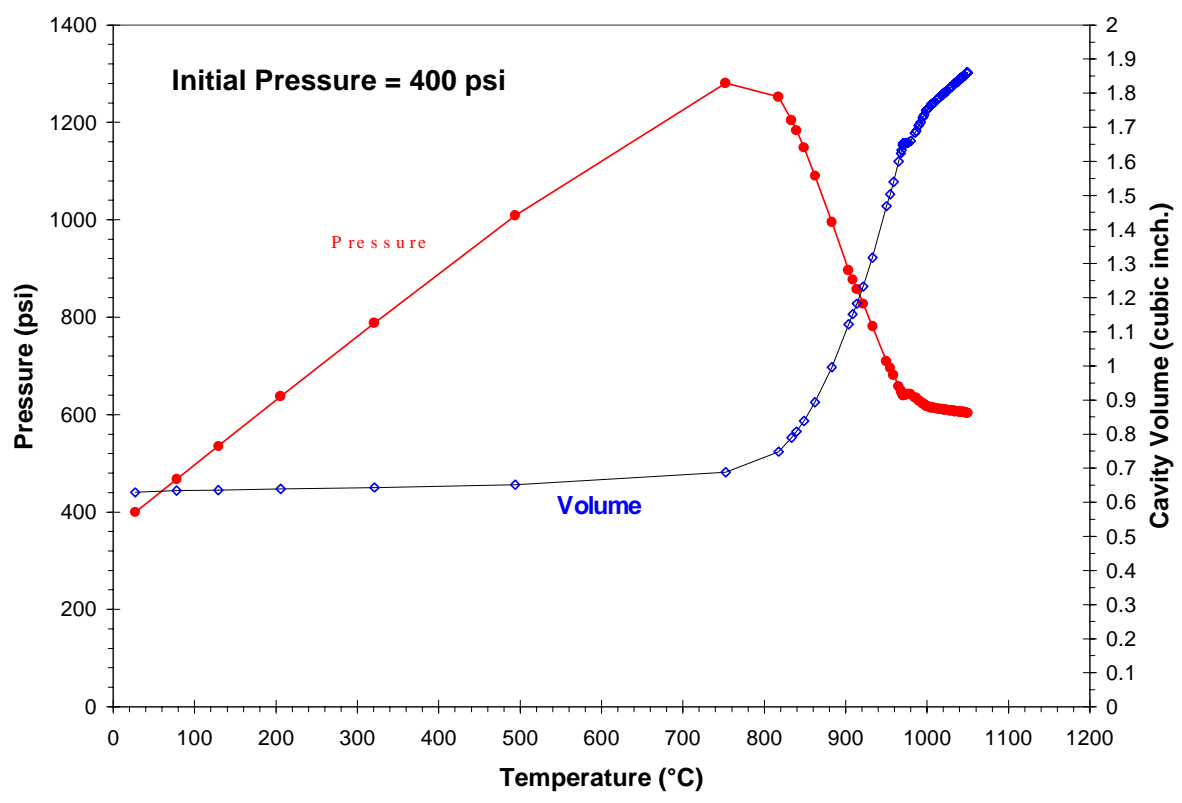

Figure 4. Calculated pressure and cavity volume changes as a function of temperature for the Type I expanding ring. 


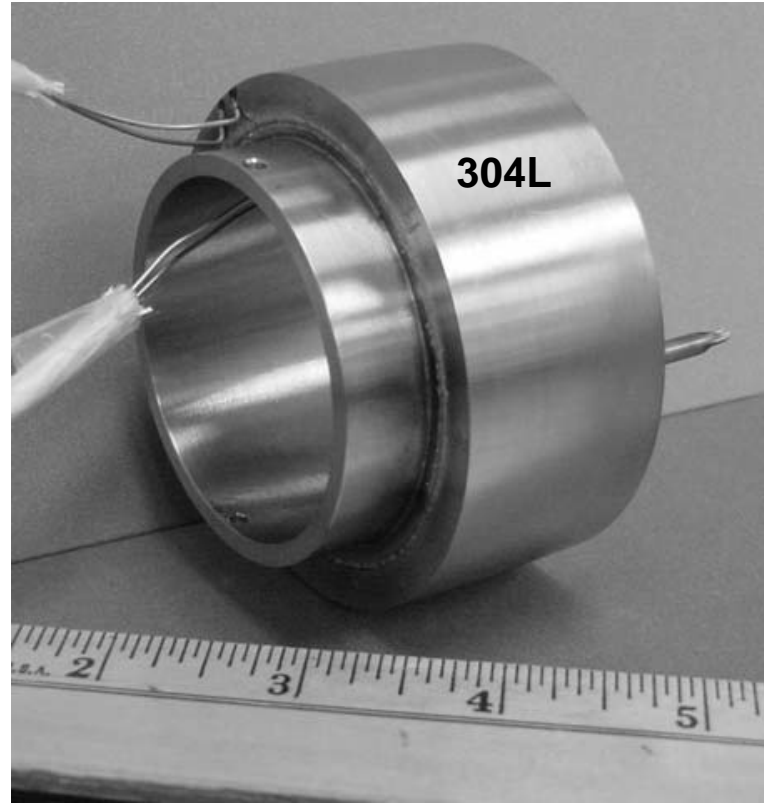

(a)

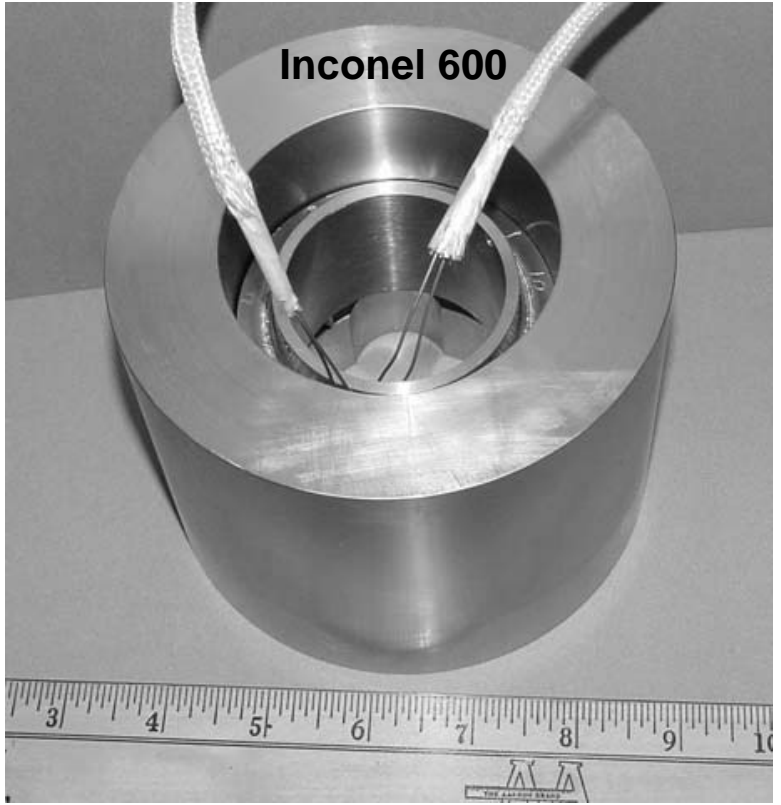

(b)

Figure 5. Initial proof of principle test prior to elevated temperature exposure. a) $304 \mathrm{~L}$ expanding ring and b) Inconel 600 simulated pour spout.

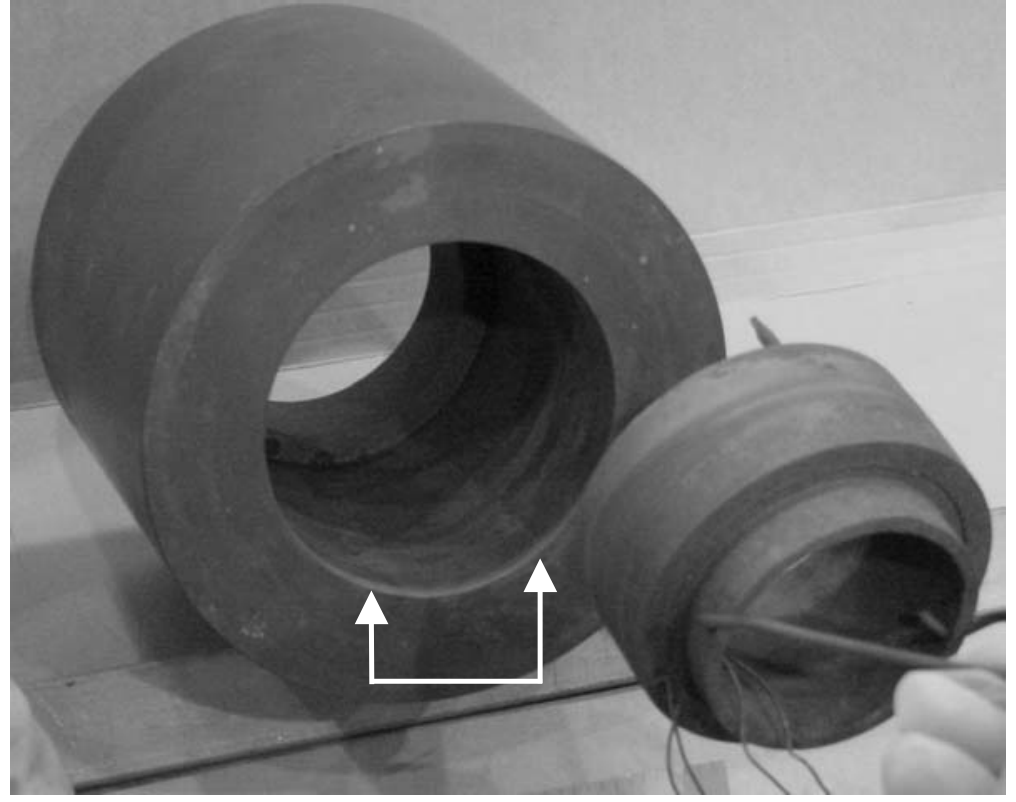

(a)

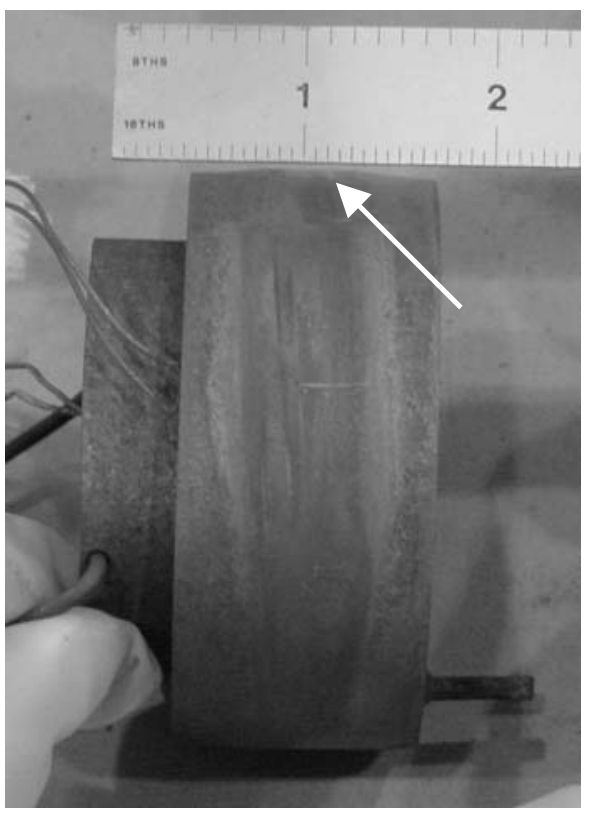

(b)

Figure 6. Initial proof of principle test following exposure at $1050{ }^{\circ} \mathrm{C}$ (Table 1 , test 1a). a) $304 \mathrm{~L}$ ring removed from Inconel 690 simulated pour spout, b) portion of ring expanded into 0.030 inch deep contoured groove (see arrow). 


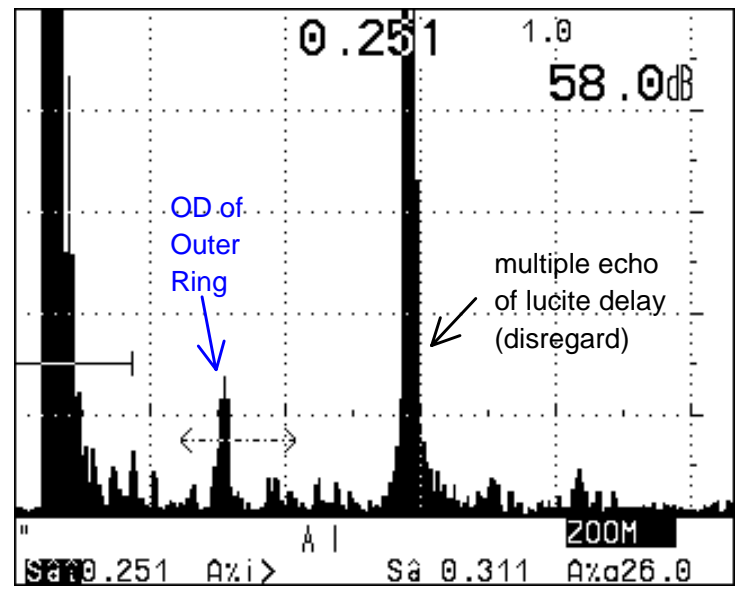

Spout wall only (0.251”)

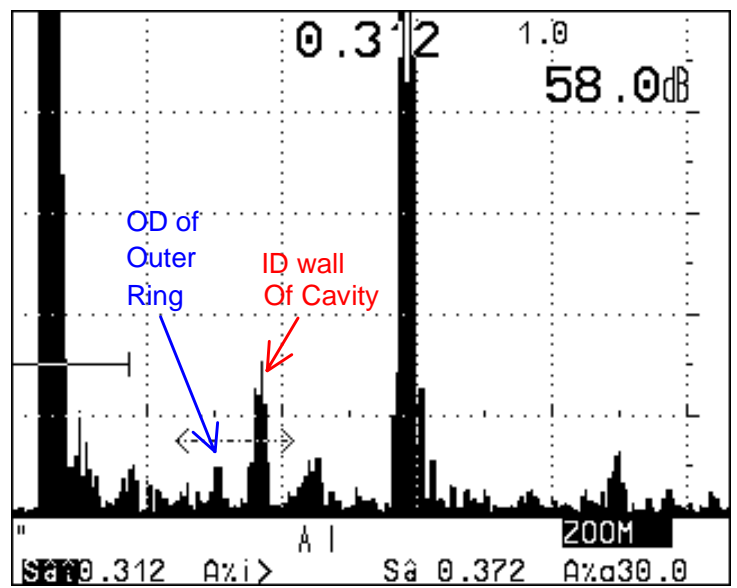

Spout and ring $(0.251+0.062$ "')

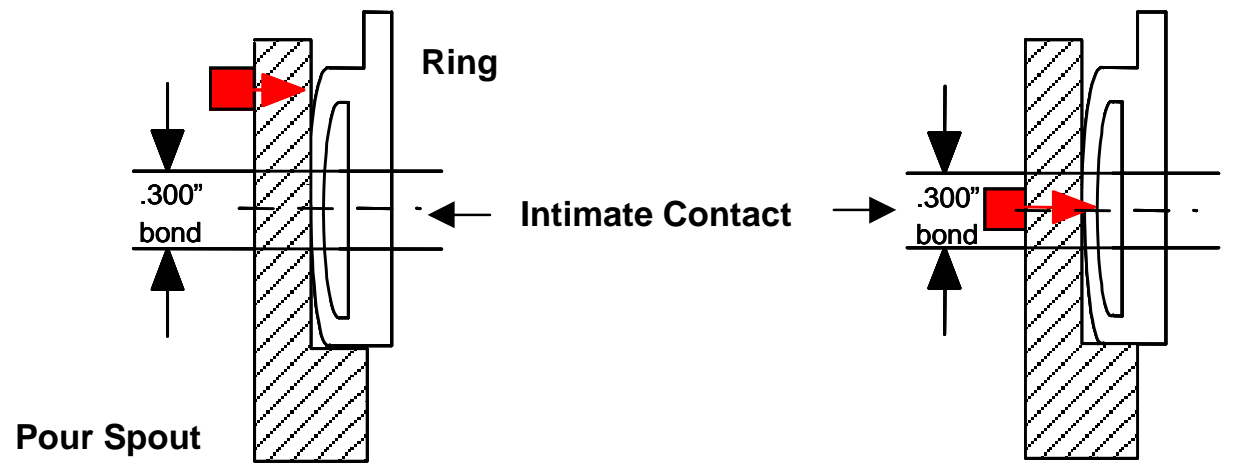

(a)

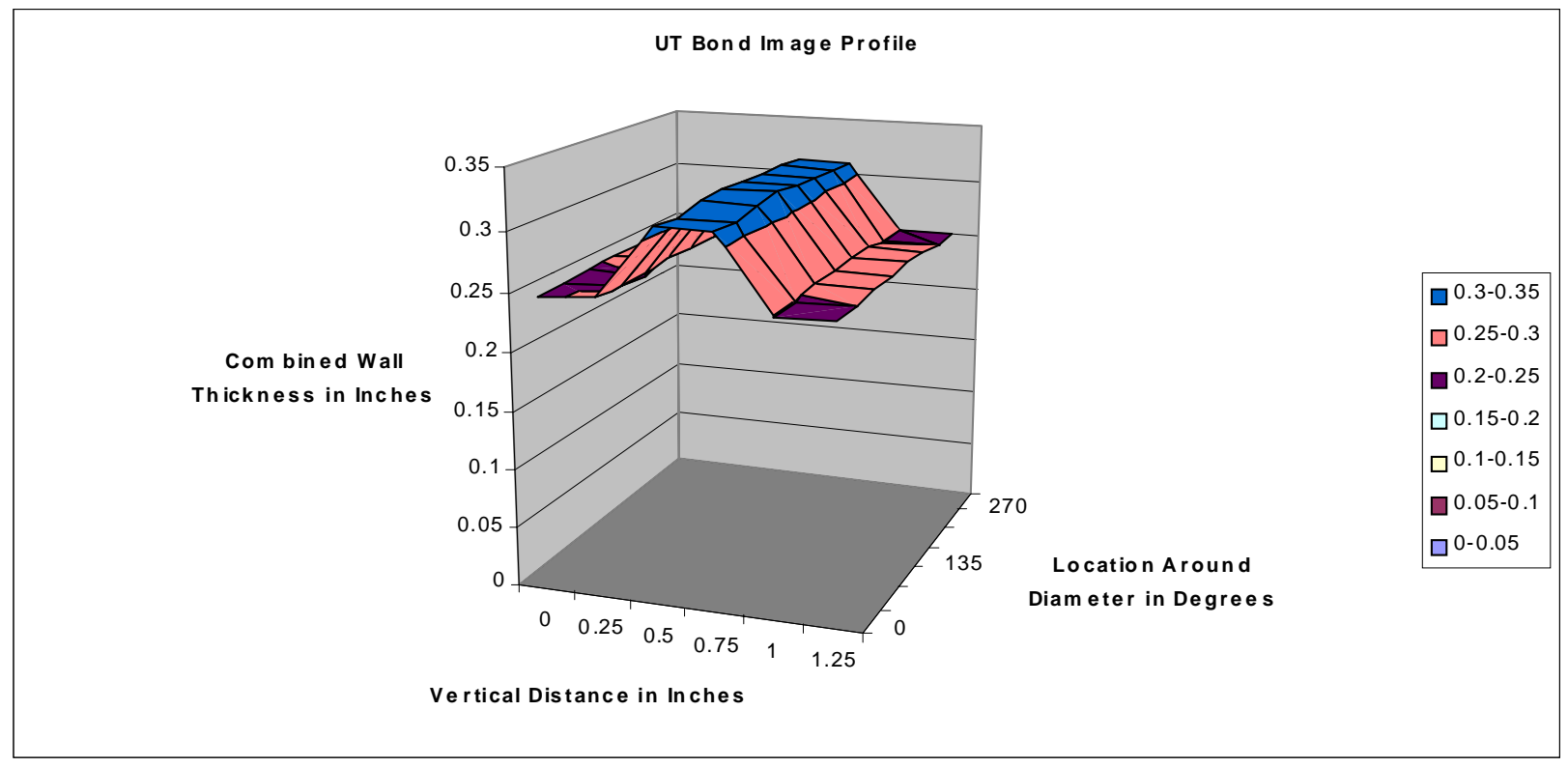

(b)

Figure 7. UT data for 304L ring and Inconel 600 spout expanded at $1050{ }^{\circ} \mathrm{C}$ with $3 / 16$ " radial clearance. a) Location of UT scan and display. b) UT data (intimate contact region in blue). 


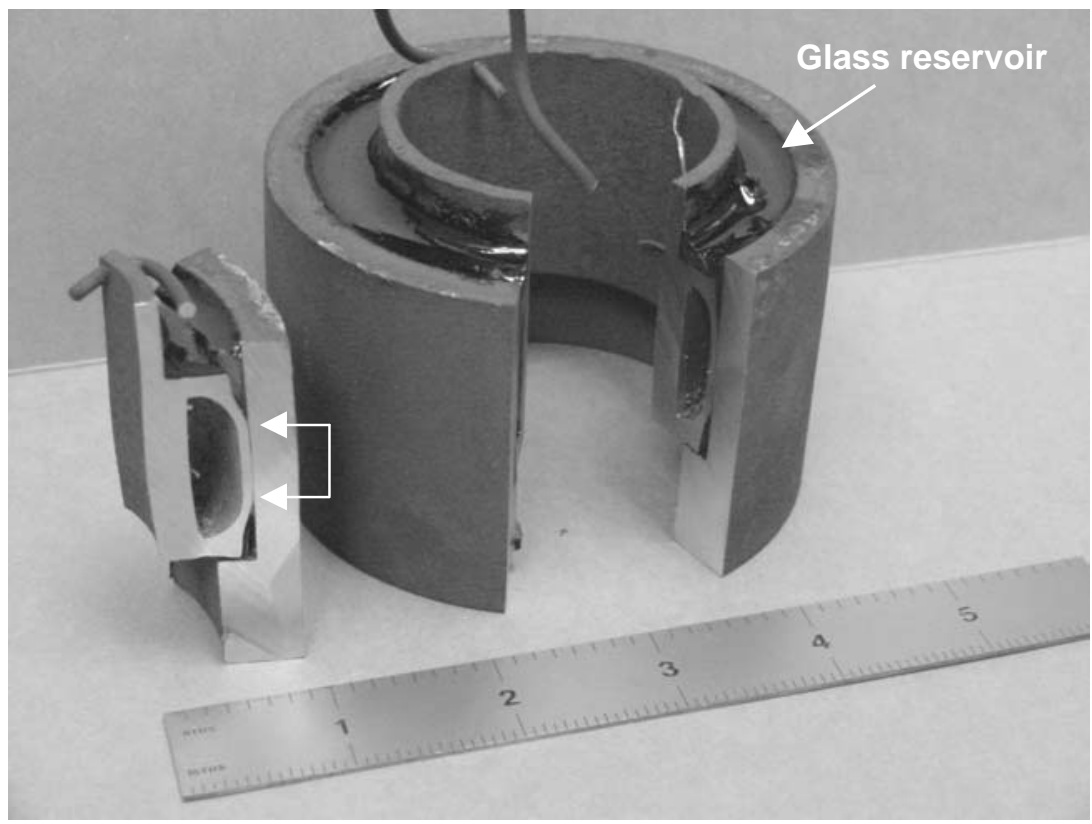

Figure 8. Destructive evaluation of 304-L ring inside 304-L simulated pour spout with 1/16 inch radial clearance after static molten glass exposure. Total axial contact was 0.75 inches, 0.30 inches of this region was in intimate contact (see arrow).

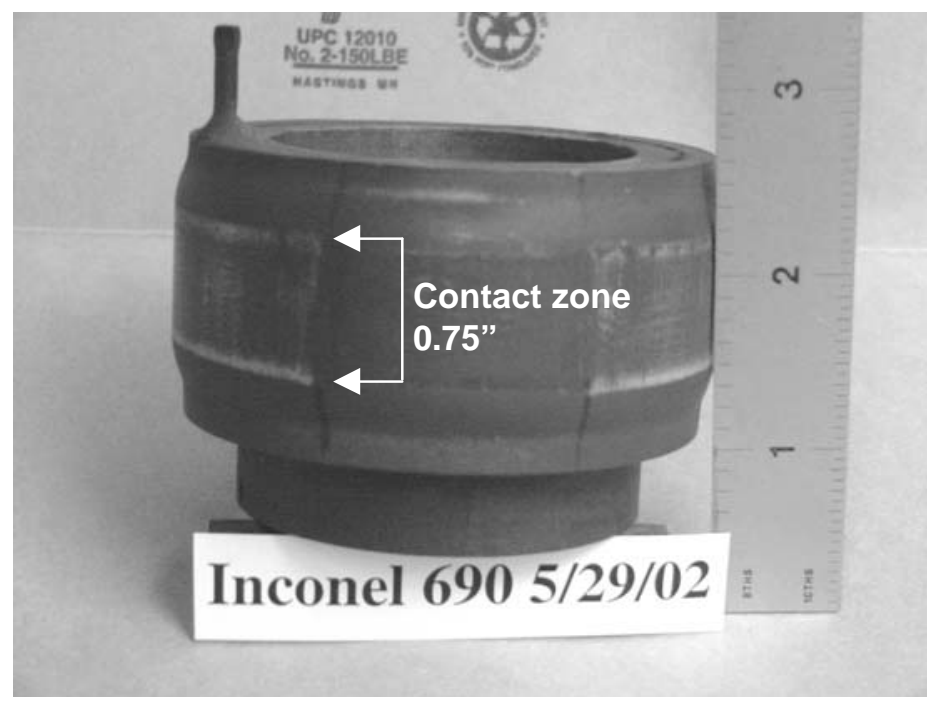

Figure 9 Expanding ring, final design, after exposure to $1100{ }^{\circ} \mathrm{C}$. Note axial contact length is approximately 0.75 inches. 


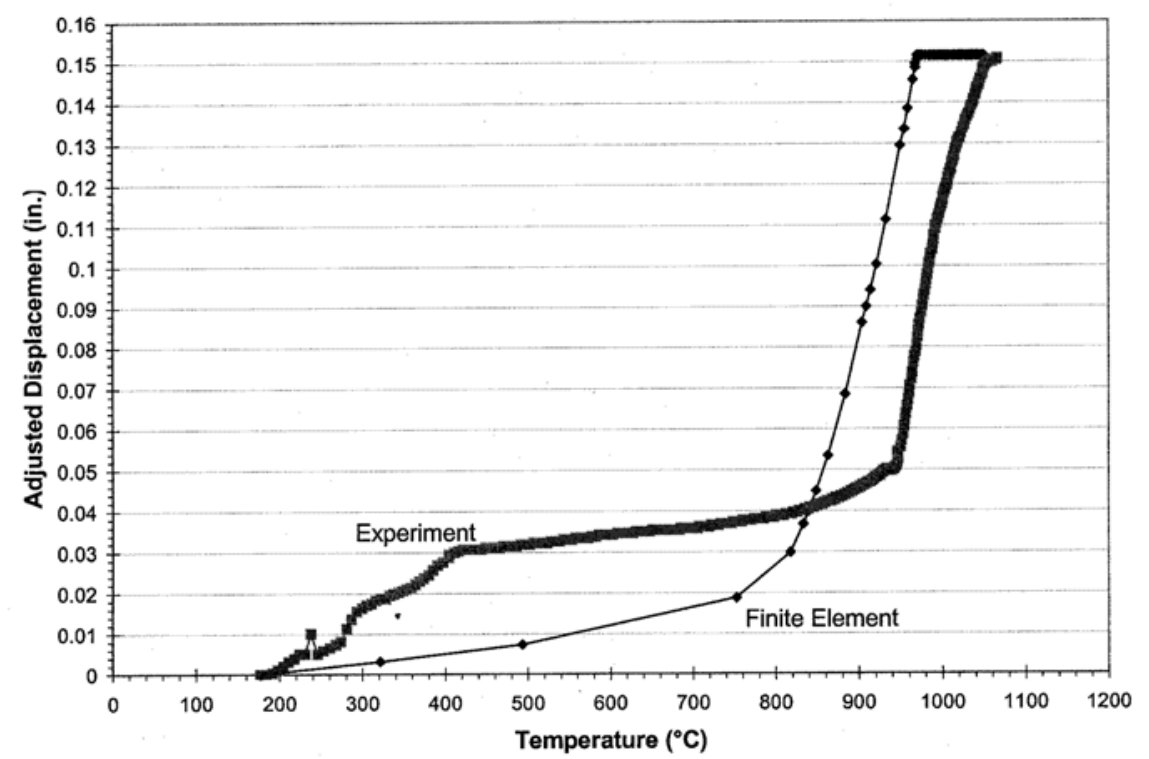

Figure 10. Experimental and calculated ring expansion for $1 / 8$ inch radial gap including 0.03 inch contoured groove.

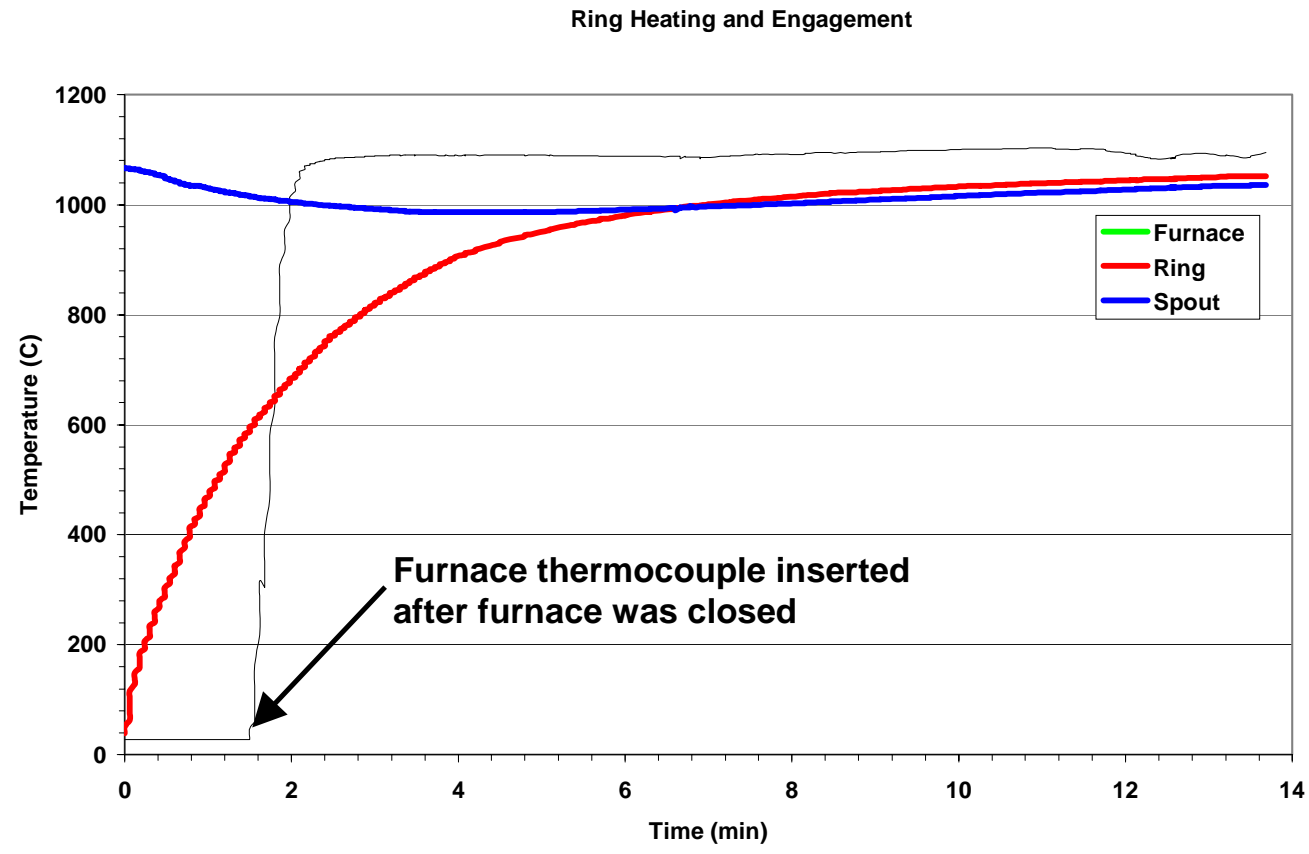

Figure 11. Temperature profile of the Inconel 690 ring in a Inconel 690 simulated pour spout heated to $1100{ }^{\circ} \mathrm{C}$. 

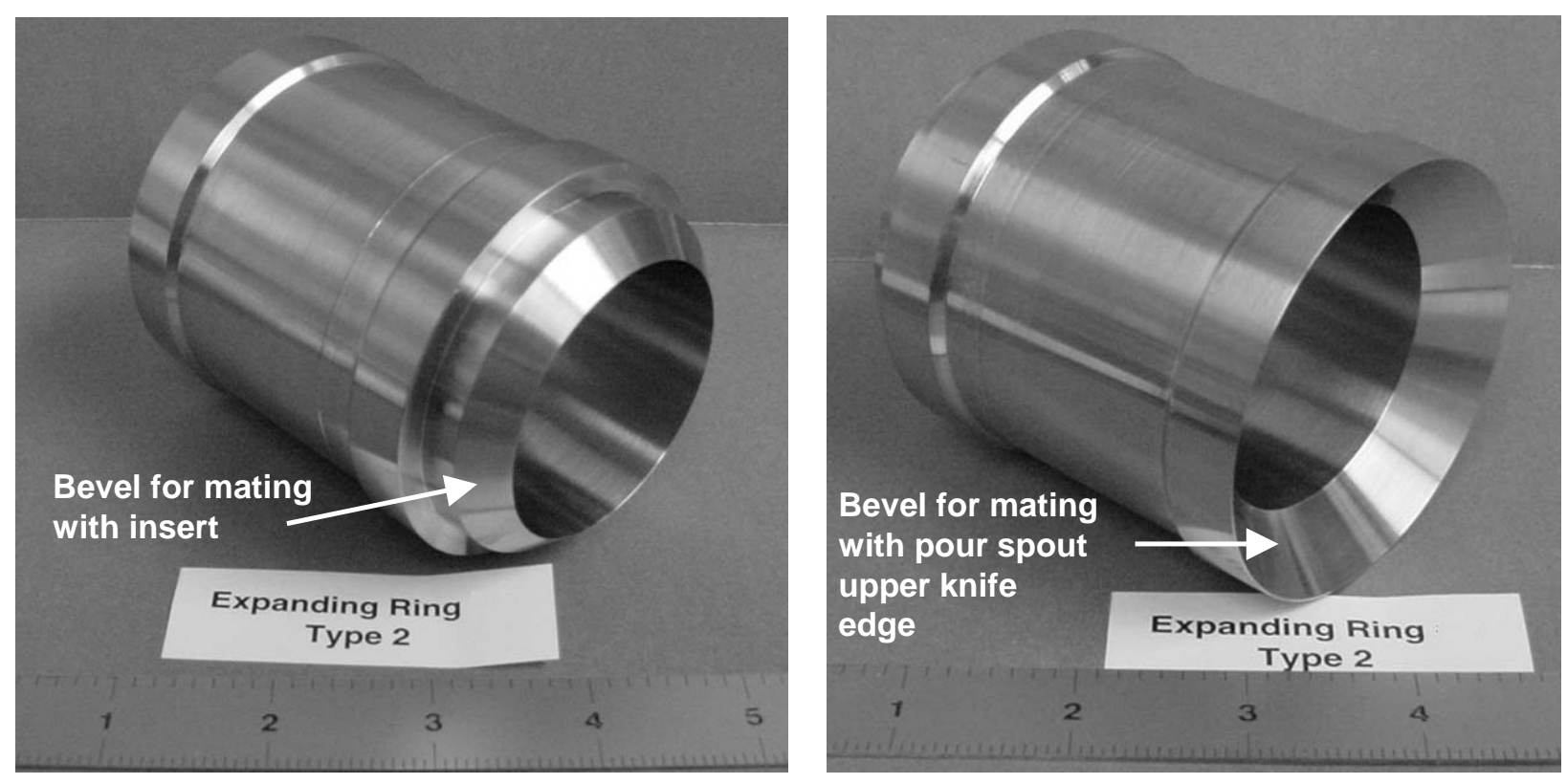

Figure 12. Photograph of the final production expanding ring assembly. 


\section{Attachment 1}

Equipment Engineering Development Drawing Number EES-22613-R3-202 Rev. B, DWPF Pour Spout Expandable Ring Weldment and Details Type II (U). Drawing to be superseded by record drawing R-R1-S-0042 Rev. A.

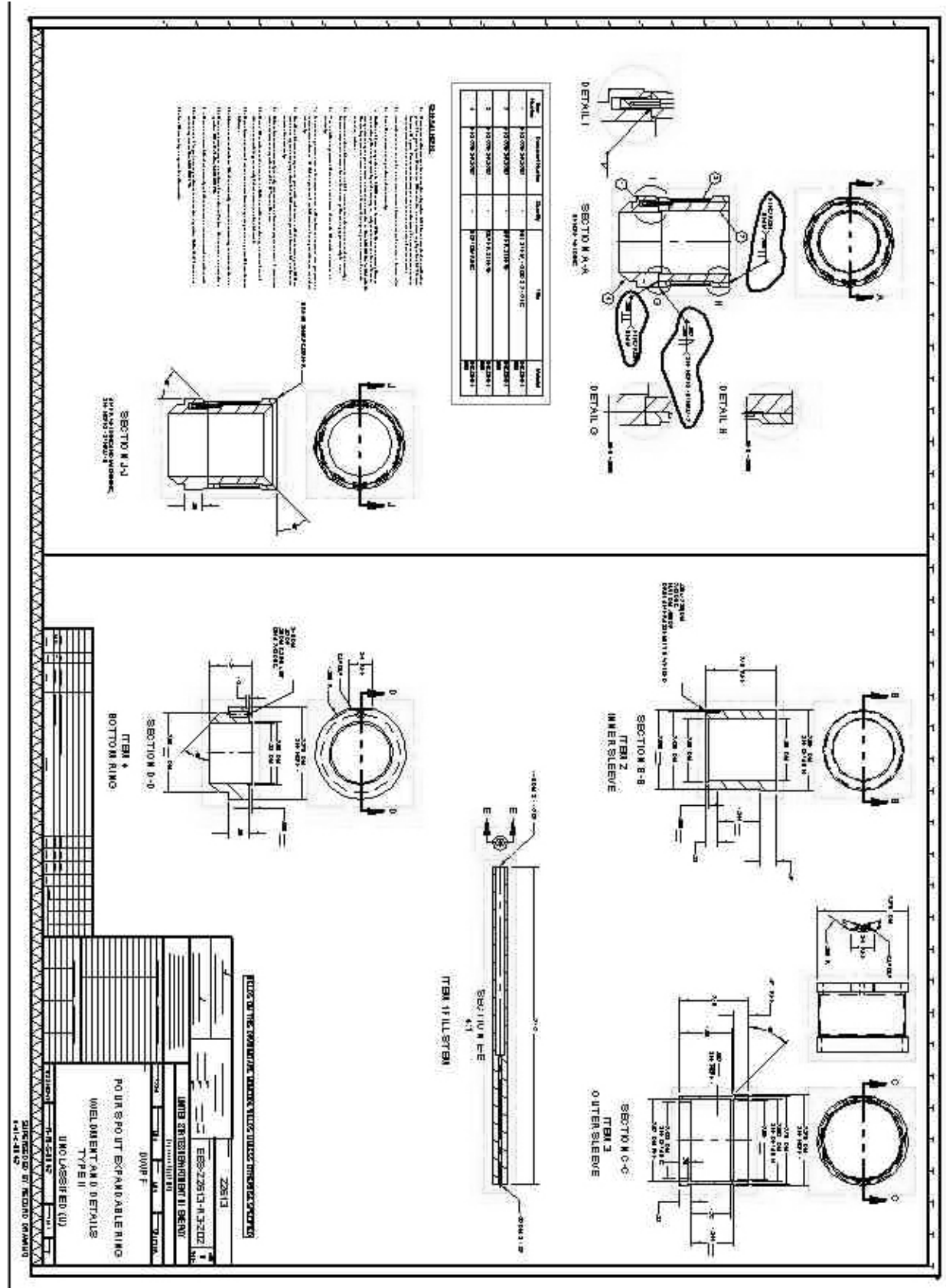

